\title{
PENDIDIKAN ANAK USIA DINI DALAM PRESPEKTIF ISLAM
}

\author{
M. Zainuddin Alanshori \\ Program Studi PIAUD, Fakultas Agama Islam, Universitas Islam Lamongan \\ Jl.Veteran No. 53 A Lamongan 62213 \\ Telp. 0322-324706/0857-3099-9931 \\ E-mail: zen.120888@gmail.com
}

\begin{abstract}
Early childhood education is a very important element. This paper aims to elaborate the principles of early childhood education based on naqliyah and aqliyah arguments as well as the nature of early childhood education in the Islamic perspectives. In addition, this paper also explains the conceptual theoretical studies of curriculum or content of Islamic education for early childhood, as well as methods that could be applied and developed in the implementation of early childhood education.
\end{abstract}

Keywords: Early Childhood Education, Curriculum, Islamic Perspective

\section{Pendahuluan}

Dalam pandangan Islam, segala sesuatu yang dilaksanakan, tentulah memiliki dasar hukum, baik itu yang berasal dari dasar naqliyah maupun dasar aqliyah. Begitu juga halnya dengan pelaksanakan pendidikan pada anak usia dini. Berkaitan dengan pelaksanaan pendidikan anak usia dini, dapat dibaca firman Allah berikut ini:

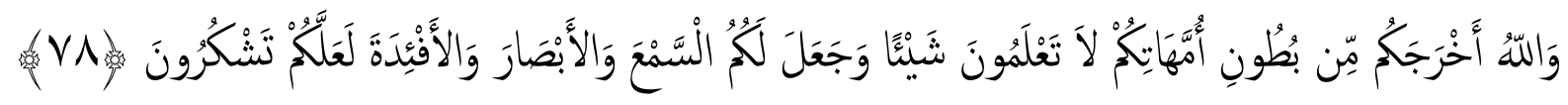
Artinya: "Dan Allah mengeluarkan kamu dari perut ibumu dalam keadaan tidak mengetahui sesuatupun, dan Dia memberi kamu pendengaran, penglihatan dan hati, agar kamu bersyukur". ${ }^{1}$

Berdasarkan ayat tersebut di atas, dipahami bahwa anak lahir dalam keadaan lemah tak berdaya dan tidak mengetahui (tidak memiliki pengetahuan) apapun. Akan tetapi Allah membekali anak yang baru lahir tersebut dengan pendengaran, penglihatan dan hati nurani (yakni akal yang menurut pendapat yang sahih pusatnya berada di hati). Menurut pendapat yang lain adalah otak. Dengan itu manusia dapat membedakan di antara segala sesuatu, mana yang bermanfaat dan mana yang berbahaya. Kemampuan dan indera ini diperoleh seseorang secara bertahap, yakni sedikit demi sedikit. Semakin besar seseorang maka bertambah pula kemampuan pendengaran, penglihatan, dan akalnya hingga sampailah ia pada usia matang dan dewasanya ${ }^{2}$. Dengan bekal pendengaran, penglihatan dan hati nurani (akal) itu, anak pada perkembangan selanjutnya akan memperoleh pengaruh sekaligus berbagai didikan dari lingkungan sekitarnya. Hal ini pula yang sejalan dengan sabda Rasul berikut ini:

\footnotetext{
${ }^{1}$ QS. An Nahl: 78.

2 Al Imam Abul Fida Ismail Ibnu Kasir Ad-Dimasyqi, Tafsir Al Qur'an al-'Ażìm, terjemahan Bahrum Abu Bakar, Tafsir Ibnu Kaśír juz 14 (Bandung: Sinar Baru Algesindo, 2003), 216.
} 


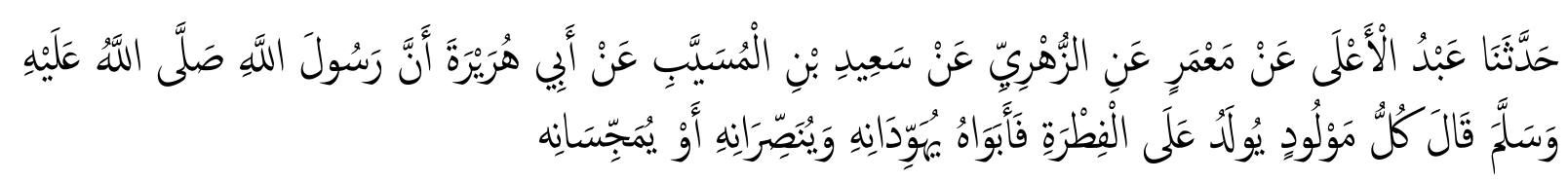

Artinya: "Setiap anak dilahirkan dalam keadaan fitrah, maka kedua orang tuanyalah yang menjadikan anak tersebut beragama Yahudi, Nasrani ataupun Majusi”.(HR. Bukhari, Abu Daud, Ahmad). ${ }^{3}$

Meskipun anak lahir dalam keadaan lemah tak berdaya serta tidak mengetahui apa-apa, tetapi ia lahir dalam keadaan fitrah, yakni suci dan bersih dari segala macam keburukan. Karenanya untuk memelihara sekaligus mengembangkan fitrah yang ada pada anak, orang tua berkewajiban memberikan didikan positif kepada anak sejak usia dini.

Dalam pandangan Islam anak merupakan amanah di tangan kedua orang tuanya. Hatinya yang bersih merupakan permata yang berharga, lugu dan bebas dari segala macam ukiran dan gambaran. Ukiran berupa didikan yang baik akan tumbuh subur pada diri anak, sehingga ia akan berkembang dengan baik dan sesuai ajaran Islam, dan pada akhirnya akan meraih kebahagiaan di dunia dan di akhirat. Jika anak sejak dini dibisakan dan dididik dengan hal-hal yang baik dan diajarkan kebaikan kepadanya, ia akan tumbuh dan berkembang dengan baik dan akan memperoleh kebahagiaan serta terhindar dari kesengaraan/siksa baik dalam hidupnya di dunia maupun di akhirat kelak.

Berdasarkan ayat tersebut, dipahami bahwa orang tua memiliki kewajiban untuk memelihara diri dan keluarga (anak-anaknya) dari siksaan api neraka. Cara yang dapat dilakukan oleh orang tua ialah mendidiknya, membimbingnya dan mengajari akhlak-akhlak yang baik, serta mengawasi pertumbuhannya dengan cermat dan bijaksana sesuai dengan tuntutan pendidikan Islam.

Dari uraian di atas kiranya dapat disebutkan bahwa tujuan pendidikan anak usia dini dalam pandangan Islam adalah memelihara, membantu pertumbuhan dan perkembangan fitrah manusia yang dimiliki anak, sehingga jiwa anak yang lahir dalam kondisi fitrah tidak terkotori oleh kehidupan duniawi yang dapat menjadikan anak sebagai Yahudi, Nasrani atau Majusi. Atau dengan kata lain bahwa pendidikan anak usia dini dalam pendidikan Islam bertujuan untuk menanamkan nilai-nilai keislaman kepada anak sejak dini, sehinga dalam perkembangan selanjutnya anak menjadi manusia muslim yang käffah, yang beriman dan bertaqwa kepada Allah SWT. Hidupnya terhindar dari kemaksiatan, dan dihiasi dengan ketaatan dan kepatuhan serta oleh amal soleh yang tiada hentinya. Kondisi seperti inilah yang dikehendaki oleh pendidikan Islam, sehingga kelak akan mengantarkan peserta didik pada kehidupan yang bahagia di dunia maupun di akhirat.

Selanjutnya melalui tulisan ini, penulis akan mencoba menjabarkan telaah teoritis konseptual tentang isi kurikulum serta materi pendidikan islam anak usia dini dan metodemetode pendidikan islam yang bisa dikembangkan dalam membimbing dan menumbuhkan nilai-nilai kebaikan dan keislaman pada anak usia dini.

\section{Kurikulum dan Materi Pendidikan Anak Usia Dini}

\footnotetext{
${ }^{3}$ Abu Abdullah ibn Muhammad Isma'il al-Bukhari, Shahih Bukhri Juz I (Riyadh: Idaratul Bahtsi Ilmiah,tt), 25.
} 
Ada berbagai bentuk kurikulum yang dikembangkan oleh para ahli dalam pendidikan anak usia dini. Ada yang disebut dengan Kurikulum terpisah-pisah, yakni kurikulum mempunyai mata pelajaran yang tersendiri satu dengan lainnya tidak ada kaitannya, karena masing-masing mata pelajaran mempunyai organisasi yang terintegrasikan. Ada pula Kurikulum saling berkaitan, yakni antara masing-masing mata pelajaran ada keterkaitan, antara dua mata pelajaran masih ada kaitannya. Dengan demikian anak mendapat kesempatan untuk melihat keterkaitan antara mata pelajaran, sehingga anak masih dapat belajar mengintegrasikan walaupun hanya antara dua mata pelajaran. Kemudian ada pula yang dinamai dengan Kurikuluim Terintegrasikan, dalam kurikulum ini anak mendapat pengalaman luas, karena antara satu mata pelajaran dengan mata pelajaran lain saling berkaitan. $^{4}$

Dalam kaitannya dengan materi pendidikan untuk anak usia dini, Ibnu Sina telah menyebutkan dalam bukunya yang berjudul As-Siyasah, ide-ide yang cemerlang dalam mendidik anak. Dia menasihati agar dalam mendidik anak dimulai dengan mengajarkannya al Qur'an al-Karim yang merupakan persiapan fisik dan mental untuk belajar. Pada waktu itu juga anak-anak belajar mengenal huruf-huruf hijaiyah, cara membaca, menulis dan dasardasar agama. ${ }^{5}$

Setelah itu mereka belajar meriwayatkan sya'ir yang dimulai dari rojaz kemudian qashidah karena meriwayatkan dan menghafal rojaz lebih mudah sebab bait-baitnya lebih pendek dan wajn (timbangan)nya lebih ringan. Sebaiknya dalam hal ini, guru memilih sya'ir tentang adab-adab yang terpuji, kemuliaan orang-orang yang berilmu dan hinanya orangorang yang bodoh, mendorong untuk berbakti kepada orang tua, anjuran melakukan amar ma'ruf dan memuliakan tamu. ${ }^{6}$

Apabila anak-anak sudah bisa menghafal Al-Qur'an al-Karim dan mengetahui qaidahqaidah bahasa Arab dengan baik, maka untuk mengarahkan ke jenjang berikutnya adalah dengan melihat kecenderungannya atau apa yang sesuai dengan tabiat dan bakatnya. Di dalam nasihat terakhir tersebut Ibnu Sina menyebutkan pengarahan guru yang disesuaikan dengan kecenderungan atau apa yang sesuai dengan bakat anak, merupakan ruh (inti) pendidikan modern di jaman kita ini. Para pakar pendidikan sekarang mengajak untuk selalu memperhatikan kesiapan dan kecenderungan anak-anak didik dalam belajar, mereka diarahkan ke dalam masalah teori maupun praktik yang meliputi masalah adab, olah raga, agama, sosial dan kesenian sesuai dengan kecenderungan mereka, agar mereka sukses dalam belajarnya. $^{7}$

Dengan demikian seluruh mata pelajaran merupakan satu kesatuan yang utuh atau bulat. Adapun pokok-pokok pendidikan yang harus diberikan kepada anak, adalah meliputi seluruh ajaran Islam yang secara garis besar dapat dikelompokan menjadi tiga, yakni, aqidah, ibadah dan akhlak serta dilengkapi dengan pendidikan membaca Al Qur'an.

1. Pendidikan akidah, hal ini diberikan karena Islam menempatkan pendidikan akidah pada posisi yang paling mendasar, terlebih lagi bagi kehidupan anak, sehingga dasar-dasar

\footnotetext{
${ }^{4} \mathrm{M}$. Athiyah $\mathrm{Al}$ Abrasy, at-Tarbiyah al-Islāmiyah wa Falasatuhā (TTp: 'Isa al-Bābi al-Jalabī wa syirkāhu,1969),163.

${ }^{5}$ Ibid

${ }^{6} \mathrm{Ibid}$

${ }^{7}$ Ibid
} 
akidah harus terus-menerus ditanamkan pada diri anak agar setiap perkembangan dan pertumbuhannya senantiasa dilandasi oleh akidah yang benar.

2. Pendidikan ibadah, hal ini juga penting bagi pertumbuhan dan perkembangan anak usia dini. Karenanya tata peribadatan menyeluruh sebagaimana termaktub dalam fiqih Islam hendaklah diperkenalkan sedini mungkin dan dibiasakan dalam diri anak sejak usia dini. Hal ini dilakukan agar kelak mereka tumbuh menjadi insan yang benar-benar takwa, yakni insan yang taat melaksanakan segala perintah agama dan taat pula dalam menjauhi segala larangannya.

3. Pendidikan akhlak, dalam rangka mendidik akhlak kepada anak-anak, selain harus diberikan keteladanan yang tepat, juga harus ditunjukkan tentang bagaimana menghormati dan bertata krama dengan orang tua, guru, saudara (kakak dan adiknya) serta bersopan santun dalam bergaul dengan sesama manusia. Alangkah bijaksananya jika para orangtua atau orang dewasa lainnya telah memulai dan menanamkan pendidikan akhlak kepada anak-anaknya sejak usia dini, apa lagi jika dilaksanakan secara terprogram dan rutin.

Dalam rangka mengoptimalkan perkembangan anak dan memenuhi karakteristik anak yang merupakan individu unik, yang mempunyai pengalaman dan pengetahuan yang berbeda, maka perlu dilakukan usaha yaitu dengan memberikan rangsangan-rangsangan, dorongandorongan, dan dukungan kepada anak. Agar para pendidik dapat melakukan dengan optimal maka perlu disiapkan suatu kurikulum yang sistematis. Selain pembentukan sikap dan perilaku yang baik, anak juga memerlukan kemampuan intelektual agar anak siap menghadapi tuntutan masa kini dan masa datang. Sehubungan dengan itu maka program pendidikan dapat mencakup bidang pembentukan sikap dan pengembangan kemampuan dasar yang keseluruhannya berguna untuk mewujudkan manusia sempurna yang mampu berdiri sendiri, bertanggung jawab dan mempunyai bekal untuk memasuki pendidikan selanjutnya. Karenanya kurikulum untuk anak usia dini sebaiknya memperhatikan beberapa prinsip. Pertama, berpusat pada anak, artinya anak merupakan sasaran dalam kegiatan pembelajaran yang dilakukan oleh pendidik. Kedua, mendorong perkembangan fisik, daya pikir, daya cipta, sosial emosional, bahasa dan komunikasi sebagai dasar pembentukan pribadi manusia yangh utuh. Ketiga, memperhatikan perbedaan anak, baik perbedaan keadaan jasmani, rohani, kecerdasan dan tingkat perkembangannya. Pengembangan program harus memperhatikan kesesuaian dengan tingkat perkembangan anak (Developmentally Appropriate Program $)^{8}$.

Acuan menu pembelajaran pada Pendidikan Anak Usia Dini telah mengembangkan program kegiatan belajar anak usia dini. Program tersebut dikelompokkan dalam enam kelompok usia, yaitu lahir -1 tahun, $1-2$ tahun, $2-3$ tahun, $3-4$ tahun, $5-6$ tahun dan $5-$ 6 tahun. Masing-masing kelompok usia dibagi dalam enam aspek perkembangan yaitu: perkembangan moral dan nilai-nilai agama, perkembangan fisik, perkembangan bahasa, perkembangan kognitif, perkembangan sosial emosional, dan perkembangan seni dan kreativitas.

Sesuai dengan dasar, tujuan dan kompetensi pendidikan anak usia dini, maka ada beberapa materi pokok yang harus diajarkan kepada anak-anak di usia dini. Dalam konsep Islam, secara umum materi yang harus diajarkan kepada anak usia dini, sama dengan materi dasar ajaran Islam yang terdiri dari bidang aqidah, ibadah, dan akhlak. Dalam pembelajaran

\footnotetext{
${ }^{8}$ M. Nipan Abdul Halim, Anak Saleh Dambaan Keluarga (Jakarta: Mitra Pustaka, 2001), 25
} 
terhadap anak usia dini, tentu saja uraian materi yang diberikan tidaklah sama dengan yang diberikan kepada orang dewasa, meskipun masih berada dalam lingkup akidah, ibadah dan akhlak.

Pada bidang aqidah, meskipun anak usia dini belum layak untuk diajak berpikir tentang hakikat Tuhan, malaikat, nabi (rasul), kitab suci, hari akhir, dan qadha dan qadar, tetapi anak usia dini sudah dapat diberi pendidikan awal tentang aqidah (rukun Iman). Pendidikan awal tentang aqidah, bisa saja diberikan materi yang berupa mengenal nama-nama Allah dan ciptaan-Nya yang ada di sekitar kehidupan anak, nama-nama malaikat, kisah-kisah Nabi dan Rasul, dan materi dasar lainnya yang berkaitan dengan aqidah (rukun Iman). Di antara yang dapat dilakukan dalam memberi pendidikan aqidah kepada anak ialah dengan cara mengazankan anak yang baru lahir, sebagaimana diperintahkan rasul dalam sabdanya:

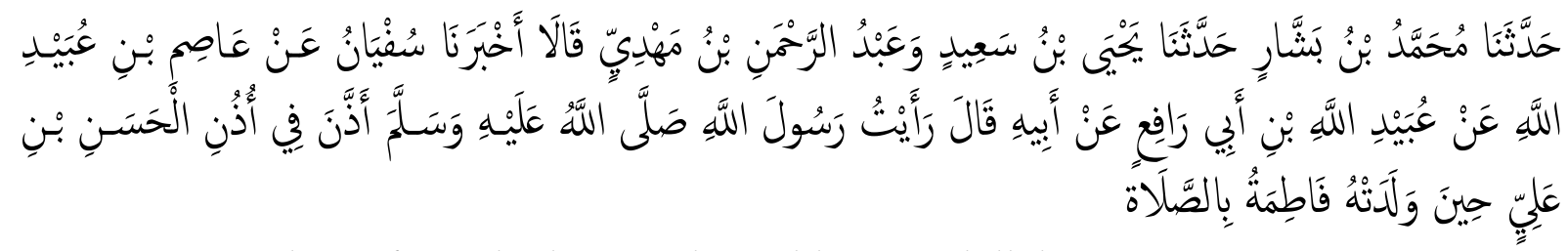

Artinya: Dari Abu Rafi', ia berkata, "Aku melihat Rasulullah SAW ażan sebagaimana ażan şalat, di telinga Husain bin Ali ketika Fathimah melahirkannya”(HR. at-Tirmizi). ${ }^{9}$

Ibnu Qayyim seperti dikutip oleh Al Mun'im Ibrahim, menyebutkan bahwa rahasia azan adalah agar awal yang didengar bagi seorang yang baru dilahirkan adalah azan yang mengandung keagungan dan keluhuran Tuhan. Sebagaimana kalimat syahadat bagi orang yang baru masuk Islam. Praktik tersebut merupakan pengenalan terhadap syi'ar Islam di dunia ini $^{10}$ (Quthb, 1988).

Pada usia dini anak juga perlu diberi pengajaran tentang ibadah, seperti tentang bersuci, do'a-do'a, dan ayat-ayat pendek, cara mengucap salam, dan sedikit tentang tata cara melaksanakan şalat, serta beberapa hal lain yang dikategorikan kepada amal dan perbuatan baik yang diridhoi Allah. Dalam hal memberi pendidikan şalat kepada anak di usia dini dapat dilakukan orang tua dengan mulai membimbing anak untuk mengerjakan şalat dengan mengajak melakukan şalat di sampingnya, dimulai ketika ia sudah mengetahui tangan kanan dan kirinya. Jika orang tua menghendaki anak mengerjakan şalat, berilah ia teladan. Orang tua perlu menjelaskan bahwa şalat merupakan satu wujud rasa syukur, karena Allah telah memberikan nikmat berupa rezki yang halal dan kesehatan. Hal ini dimaksudkan agar anak dapat mempelajari hukum-hukum ibadah salat sejak masa pertumbuhannya, sehingga ketika anak tumbuh besar, ia telah terbiasa melakukan dan terdidik untuk mentaati Allah, melaksanakan hak-hakNya, bersyukur kepada Allah, di samping itu anak akan mendapatkan kesucian ruh, kesehatan jasmani, kebaikan akhlak, perkataan dan perbuatan di dalam ibadah salat yang dilaksanakannya.

Dalam mengajari şalat, dapat dibaca pada firman Allah berikut ini:

\footnotetext{
${ }^{9}$ Imam al-Hafidz Abi 'Abbas Muhammad ibn 'Isa bin Saurah at-Tirmiżi, Sunan at-Tirmiżi al-Jami'us Şahih, juz 3 (Semarang: Toha Putra,tt,). 36

${ }^{10}$ Ali Quthb, Auladuna fi Dlau-it Tarbiyyat al- Islamiyyah, terjemahan Sang Anak dalam Naungan Pendidikan Islam (Bandung: Diponegoro, 1988), 48
} 


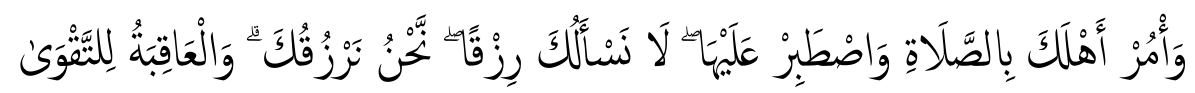

Artinya: "Dan perintahkanlah kepada keluargamu mendirikan shalat dan bersabarlah kamu dalam mengerjakannya. Kami tidak meminta rezki kepadamu, Kamilah yang memberi rezki kepadamu. Dan akibat (yang baik) itu adalah bagi orang yang bertakwa". ${ }^{11}$

Ayat ini mengandung arti, selamatkanlah mereka dari azab Allah dengan mengerjakan şalat secara rutin dan bersabarlah kamu dalam mengerjakannya. Dan karenanya dewasa ini adalah menjadi keharusan bagi setiap orang tua memberi pendidikan şalat kepada anak-anak sejak usia dini. Meskipun dalam hadis Rasul disebutkan mengajari anak şalat setelah usia 7 (tujuh), bukan berarti pada usia sebelumnya anak tidak diajari şalat sama sekali. Pada usia ini setidaknya anak dikenalkan dengan şalat misalnya kedua orang tua bisa mulai membimbing anak mengerjakan şalat dengan cara mengajak anak untuk melakukan şalat di samping mereka. Dalam mengajarkan şalat kepada anak-anak hendaklah diberikan secara bertahap, yaitu bagi anak-anak umur 7 (tujuh) tahun pertama yang diajarkan adalah tentang rukunrukun şalat, kewajiban-kewajiban dalam mengerjakan şalat serta hal-hal yang bisa membatalkan şhalat. ${ }^{12}$

Setelah itu, diajarkan pula gerak-geriknya terlebih dahulu, kemudian bacaannya secara bertahap, bacaan yang paling mudah dibaca dan dihapal anak-anak, itulah yang diajarkan terlebih dahulu, baru dilanjutkan dengan bacaan-bacaan lainnya.

Pendidikan akhlak juga merupakan materi penting untuk diberikan pada anak usia dini, hal ini senada dengan sabda Rasululah Saw:

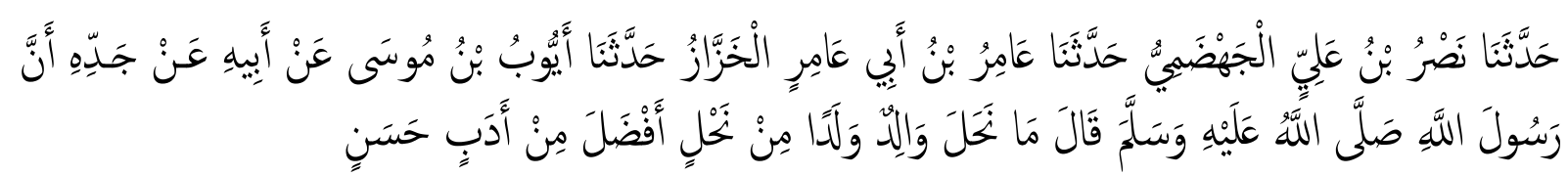

Artinya: "Tidaklah ada pemberian yang lebih baik dari seorang ayah kepada anaknya daripada akhlak yang baik" (HR. Tirmizi) ${ }^{13}$

Dalam hadis lain Rasul bersabda:

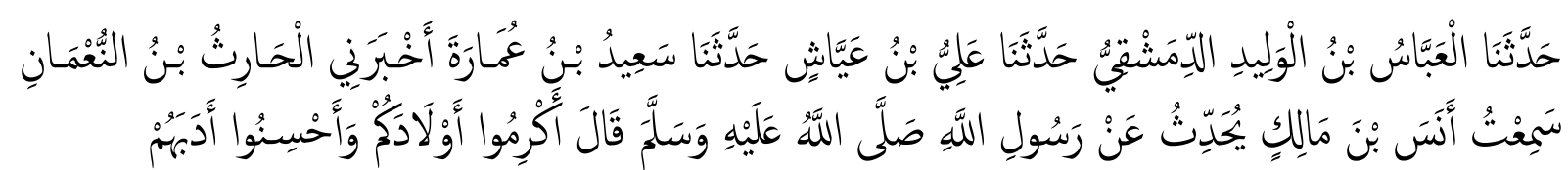

Artinya: "Muliakanlah anak-anakmu dan ajarkanlah mereka budi pekerti yang baik" (H.R. Ibnu Majah). ${ }^{14}$

\section{Metode Pendidikan Anak Usia Dini}

Untuk merealisasikan pelaksanaan kegiatan pendidikan pada anak usia dini serta guna mencapai hasil yang menggembirakan, para pendidik hendaklah senantiasa mencari berbagai metode yang efektif, serta mencari kaidah-kaidah pendidikan yang berpengaruh dalam

\footnotetext{
${ }^{11}$ QS. Thaha; 132.

12 Muhammad Suwaid, Mendidik Anak Bersama Nabi, terjemahan Salafuddin Abu Sayyid (Solo: Pustaka Arafah, 2004), 175.

${ }^{13}$ Imam al-Hafidz Abi 'Abbas Muhammad ibn 'Isa ibn Saurah at-Tirmiżi, Sunan at-Tirmiżi al-Jami'us Şahih, juz 3 (Semarang: Toha Putra,tt,). h Sunan At-Tirmizi, hadis nomor 1875.

${ }^{14}$ Abi 'Abdillah Muhammad ibn Yazid al-Quzwaini, Sunan Ibnu Mājah, juz 1 (Bairut: Dār al-Fikr,tt), 597.
} 
mempersiapkan dan membantu pertumbuhan anak usia dini, baik secara mental dan moral, spiritual dan etos sosial, sehingga anak dapat mencapai kematangan yang sempurna guna menghadapi kehidupan dan pertumbuhan selanjutnya. Dengan bersumberkan kepada Al Quran dan hadis, ada beberapa metode pendidikan Islam yang dapat dan layak diterapkan pada kegiatan pendidikan terhadap anak usia dini. Metode dimaksud adalah:

\section{Metode dengan Keteladanan}

Keteladanan dalam pendidikan Islam, merupakan metode yang berpengaruh dan terbukti berhasil dalam mempersiapkan dan membentuk aspek moral, spiritual, dan etos sosial anak sejak usia dini. Hal ini karena pendidik adalah figure terbaik dalam pandangan anak didik yang tindak tanduknya dan sopan santunnya, disadari atau tidak akan menjadi perhatian anak-anak sekaligus ditirunya. Keteladanan menjadi faktor penting dalam menentukan baik buruknya pertumbuhan dan perkembangan anak usia dini. Jika pendidik dan orang tua jujur, dapat dipercaya, berakhlak mulia, berani, dan menjauhkan diri dari perbuatan-perbuatan yang bertentangan dengan agama, maka si anak akan tumbuh dalam kejujuran, terbentuk dengan akhlak mulia, berani dan menjauhkan diri dari perbuatanperbuatan yang bertentangan dengan agama. Anak usia dini, bagaimanapun besarnya usaha yang dipersiapkan untuk kebaikannya, bagaimanapun sucinya fitrah, tidak akan mampu memenuhi prinsip-prinsip kebaikan dan pokok-pokok pendidikan utama, selama ia (anak usia dini) tidak melihat pendidik dan orang tua sebagai teladan dari nilai-nilai moral yang tinggi. Kiranya sangat mudah bagi pendidik untuk mengajari anak dengan berbagai materi pendidikan, tetapi teramat sulit bagi anak untuk melaksanakannya jika ia melihat orang yang memberikan pengajaran tidak mengamalkan-nya.

Allah swt, juga telah mengajarkan bahwa rasul yang diutus untuk menyampaikan risalah samawi kepada umat manusia, adalah seorang yang mempunyai sifat-sifat luhur, baik spiritual, moral maupun intelektual. Sehingga umat manusia meneladaninya, belajar darinya, memenuhi panggilannya, menggunakan metodenya dalam hal kemuliaan, keutamaan dan akhlak yang terpuji. Allah mengutus Muhammad Saw. Sebagai teladan yang baik bagi umat Islam sepanjang jaman, dan bagi umat manusia di setiap saat dan tempat, sebagai pelita yang menerangi dan purnama yang memberi petunjuk. Allah berfirman dalam surah Al Ahzab ayat 21:

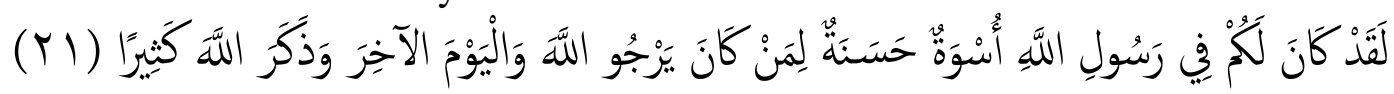

Artinya: "Sesungguhnya telah ada pada (diri) Rasulullah itu suri teladan yang baik bagimu (yaitu) bagi orang yang mengharap (rahmat) Allah dan (kedatangan) hari kiamat dan dia banyak menyebut Allah."

Ayat tersebut ditafsirkan oleh Baidhawi, bahwa uswatun hasanah yang dimaksud adalah perbuatan baik yang dapat dicontoh. Dalam ringkasan tafsir Ibnu Kasir disebutkan bahwa ayat ini merupakan prinsip utama dalam meneladani Rasulullah SAW, baik dalam ucapan, perbuatan maupun sikap dan perilakunya. ${ }^{15}$

Islam telah menyajikan pribadi Rasul sebagai suri teladan yang terus-menerus bagi seluruh pendidik, suri teladan yang selalu baru bagi generasi demi generasi, dan selalu aktual dalam kehidupan manusia, setiap kali kita membaca riwayat kehidupannya

\footnotetext{
${ }^{15}$ M. Nasib Ar-Rifa'i, Ringkasan Tafsir Ibnu Kasir, jilid 3 (Jakarta: Gema Insani, 1999), 841.
} 
bertambah pula kecintaan kita kepadanya dan tergugah pula keinginan untuk meneladaninya. Islam tidak menyajikan keteladanan ini sekedar untuk dikagumi atau sekedar untuk direnungkan dalam lautan hayal yang serba abstrak. Islam menyajikan riwayat keteladanan itu semata-mata untuk diterapkan dalam diri setiap individu muslim baik itu anak-anak maupun orang dewasa.

Dalam memberikan pendidikan kepada anak usia dini, pendidikan dengan memberi teladan secara baik dari para pendidik dan orang tua, teman bermain, pengajar, atau kakak, akan merupakan faktor yang sangat memberikan bekas dalam membina pertumbuhan anak, memberi petunjuk, dan persiapannya untuk menjadi melanjutkan kehidupannya di fasefase perkembangan selanjutnya. Dengan demikian perlu dipahami oleh para pendidik dan orang tua bahwa mendidik dengan cara memberi teladan yang baik, terutama pada masa anak usia dini sesungguhnya penopang utama dan dasar dalam meningkatkan anak usia dini pada keutamaan, kemuliaan dan etika sosial yang terpuji ${ }^{16}$.

Manusia telah diberi fitrah untuk mencari suri teladan agar menjadi pedoman bagi mereka, yang menerangi jalan kebenaran dan menjadi contoh hidup yang menjelaskan kepada mereka bagaimana seharusnya melaksanakan syrai'at Allah. Karenanya, untuk merealisasikan risalahNya di muka bumi, Allah mengutus para rasulNya yang menjelaskan kepada manusia syari'at yang diturunkan Allah kepada mereka. Anak usia dini merupakan tingkat usia yang dalam pertumbuhannya memiliki keterkaitan besar terhadap keteladanan dari pihak luar dirinya. Di dalam kehidupan berkeluarga misalnya, anak usia dini membutuhkan suri teladan, khususnya dari kedua orang tuanya, agar sejak dini (masa kanak-kanak) ia menyerap dasar tabiat perilaku Islami dan berpijak pada landasannya yang luhur.

Keteladanan yang baik memberikan pengaruh besar terhadap jiwa anak, sebab anak banyak meniru kedua orang tuanya. Anak-anak akan selalu memperhatikan dan mengawasi perilaku orang tuanya atau orang dewasa lainnya, dan mereka akan mencontohnya, jika anak mendapati orang tuanya berlaku jujur, mereka akan tumbuh dengan kejujuran. Kedua orang tua dituntut mengimplementasikan perintah-perintah Allah dan sunnah Rasul sebagai perilaku dan amalan serta terus menambah amalan-amalan sunnah tersebut semampunya, karena anak-anak akan terus mengawasi dan meniru mereka setiap waktu. Kemampuan anak dalam menerima teladan dari orang dewasa secara sadar atau tidak sadar sangatlah tinggi, meskipun anak-anak sering dianggap sebagai makhluk kecil yang belum mengerti dan paham ajaran Islam, tetapi dengan melihat teladan yang diberi orang dewasa hal itu akan memberi bekasan pada diri anak. Di sekolah, anak-anak juga membutuhkan suri teladan yang dilihatnya langsung dari setiap guru yang mendidiknya, sehingga dia merasa pasti dengan apa yang dipelajarinya. Pada perilaku dan tindakan guru-gurunya, hendaknya anak dapat melihat langsung bahwa tingkah laku utama yang diharapkan mereka melakukannya adalah hal yang tidak mustahil dan memang dalam batas kewajaran untuk direalisasikan dalam kehidupan sehari-hari. ${ }^{17}$

\footnotetext{
${ }^{16}$ Abdullah Nashih Ulwan, Tarbiyat al- Aulad Fi al- Islam, terj. Jamaluddin Miri, Pendidikan Anak dalam Islam (Jakarta: Pustaka Amani, 1995), 37.

${ }^{17}$ Abdurrahman An-Nahlawi, Prinsip-Prinsip dan Metode Pendidikan Islam dalam Keluarga di Sekolah dan di Masyarakat (Semarang: Diponegoro,1989), 366.
} 


\section{Pendidikan dengan Latihan dan Pengamalan}

Islam merupakan agama yang menuntut para pemeluknya mampu merealisasikan berbagai ajaran Islam dalam bentuk amal nyata yaitu berupa amal şaleh yang diridhai Allah SWT. Islam menuntut umatnya agar mengarahkan segala tingkah laku, naluri, aktivitas dan hidupnya untuk merealisasikan adab-adab dan perundang-undangan yang berasal dari Allah secara nyata.

Dalam hal pendidikan melalui latihan pengamalan, Rasulullah SAW, sebagai pendidik Islam yang pertama dan utama sesungguhnya telah menerapkan metode ini dan ternyata memberikan hasil yang menggembirakan bagi perkembangan Islam di kalangan sahabat. Dalam banyak hal, Rasul senantiasa mengajarkannya dengan disertai latihan pengamalannya, di antaranya; tatacara bersuci, berwudhu, melaksanakan şalat, berhaji dan berpuasa.

Atas dasar ini, maka dalam pelaksanaan pendidikan Islam baik kepada orang dewasa, apalagi terhadap anak-anak usia dini pendidikan melalui latihan dan pengamalan merupakan satu metode yang dianggap penting untuk diterapkan. Metode belajar learning by doing atau dengan jalan mengaplikasikan teori dan praktik, akan lebih memberi kesan dalam jiwa, mengokohkan ilmu di dalam kalbu dan menguatkan dalam ingatan. Di antara yang dapat dilatihkan sebagai amalan bagi anak-anak usia dini antaranya ialah; cara menggosok gigi, latihan mencuci tangan yang benar, cara beristinja, latihan berwudhu', mengucapkan salam ketika masuk rumah, serta beberapa do'a yang harus diamalkan sebagai mengawali berbagai aktivitas sehari-hari, seperti do'a hendak dan sesudah makan, do'a hendak dan bangun tidur, do'a masuk kamar mandi, dan do'a lain yang mudah diamalkan oleh anak-anak usia dini.

Orang tua wajib membiasakan atau melatih anak-anak mereka pergi ke masjid, juga melaksanakan şalat di rumah maupun di sekolah. Hal ini dapat dibaca pada hadis berikut ini:

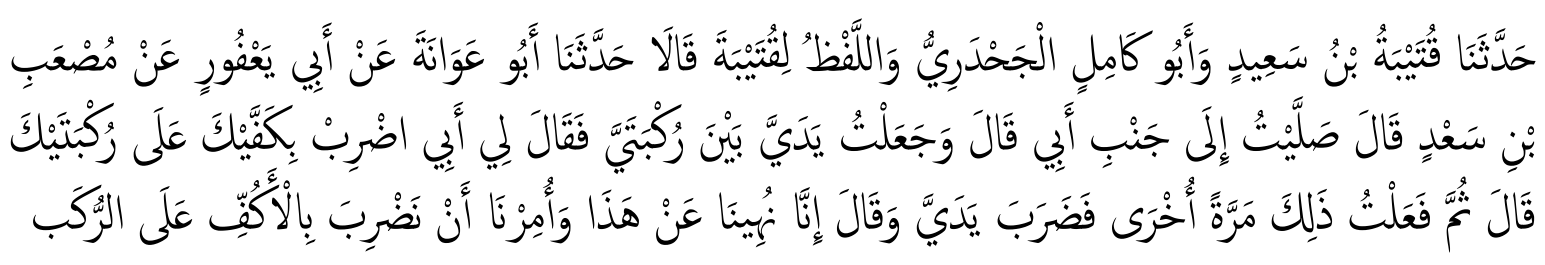

Artinya: Hadis Saad bin Abi Waqqas r.a: Diriwayatkan daripada Mus'ab bin Saad r.a katanya: Aku pernah sembahyang di sisi ayahku. Aku rapatkan tangan antara kedua lututku. Lalu ayahku berkata kepadaku: Letakkan kedua telapak tanganmu pada lututmu. Kemudian aku melakukan hal itu sekali lagi. Lalu ayah memukul tanganku sambil mengatakan: Sesungguhnya kita dilarang dari melakukan ini yaitu meletakkan tangan di antara dua lutut dan kita diperintahkan supaya meletakkan tangan di atas lutut. (HR. Muslim).

Nilai pendidikan yang terdapat dalam hadis di atas adalah tentang praktik melatih anak dalam melaksanakan şalat. Praktik pendidikan şalat seperti inilah yang seyogiyanya diterapkan oleh para orang tua dalam memberi pendidikan sholat kepada anak-anaknya, sehingga anak tidak hanya memiliki pengetahuan teoritis tentang şalat, tetapi juga memiliki pengetahuan dan pemahaman yang sifatnya praktis tentang şalat, dan dengan demikian 
maka anak akan mampu melaksanakan şalat dengan benar sesuai dengan yang diajarkan oleh Rasulullah SAW.

\section{Mendidik dengan Targhib dan Tarhib}

Targhib adalah janji yang disertai dengan bujukan dan membuat senang terhadap sesuatu maslahat, kenikmatan, atau kesenangan akhirat. Sedangkan tarhib adalah ancaman dengan siksaan sebagai akibat melakukan dosa atau kesalahan yang dilarang oleh Allah, atau akibat lengah dalam menjalankan kewajiban yang diperintahkan Allah. ${ }^{18}$

Ini merupakan metode pendidikan Islam yang didasarkan atas fitrah yang diberikan Allah kepada manusia, seperti keinginan terhadap kekuatan, kenikmatan, kesenangan, dan kehidupan abadi yang baik serta ketakutan akan kepedihan, kesengsaraan dan kesudahan yang buruk. Ditinjau dari segi paedagogis, hal ini mengandung anjuran, hendaknya pendidik dan atau orang tua menanamkan keimanan dan aqidah yang benar di dalam jiwa anak-anak, agar pendidik dapat menjanjikan (targhib) surga kepada mereka dan mengancam (tarhib) mereka dengan azab Allah, sehingga hal ini diharapkan akan mengundang anak didik untuk merealisasikan dalam bentuk amal dan perbuatan yang dianjurkan oleh ajaran Islam. Dalam memberikan pendidikan melalui targhib dan tarhib, pendidik hendaknya lebih mengutamakan pemberian gambaran yang indah tentang kenikmatan di surga dan berbagai kenikmatan lain yang diperoleh sebagai balasan bagi amal sholeh yang dikerjakan, sekaligus juga diberikan sedikit gambaran tentang dahsyatnya azab Allah yang diberikan sebagai ganjaran pelanggaran yang dilakukan.

Pendidikan dengan menerapkan metode ini merupakan upaya untuk menggugah, mendidik dan mengembangkan perasaan Rabbaniyah pada anak sejak usia dini, perasaanperasaan yang diharapkan dapat dikembangkan melalui metode ini antara lain; khauf kepada Allah, perasaan khusyu', perasaan cinta kepada Allah, dan perasaan raja' (berharap) kepada Allah.

Targhib dan tarhib merupakan bagian dari metode kejiwaan yang sangat menentukan dalam meluruskan anak, ia merupakan cara yang jelas dan gamblang dalam pendidikan ala Rasul, beliau sering menggunakannya dalam menyelesaikan masalah anak di segala kesempatan, terutama dalam masalah berbakti kepada orang tua. Beliau mendorong anak agar berbakti kepada kedua orang tuanya serta menakut-nakutinya dari berbuat durhaka kepada keduanya. Hal itu tidak lain bertujuan agar anak itu menyambut hal ini dan mendapatkan pengaruh sehingga ia bisa memperbaiki diri dan perilakunya. ${ }^{19}$

\section{Pujian dan Sanjungan}

Tidak diragukan lagi, pujian terhadap anak mempunyai pengaruh yang sangat dominan terhadap dirinya, sehingga hal itu akan menggerakkan perasaan dan inderanya. Dengan demikian, seorang anak akan bergegas meluruskan perilaku dan perbuatannya. Jiwanya akan menjadi riang dan juga senang dengan pujian ini untuk kemudian semakin aktif. Rasulullah sebagai manusia yang mengerti tentang kejiwaan manusia telah

\footnotetext{
${ }^{18}$ Ibid., 412.

19 Muhammad Suwaid, Mendidik Anak Bersama Nabi, terjemahan Salafuddin Abu Sayyid (Solo: Pustaka Arafah, 2004), 175.
} 
mengingatkan akan pujian yang memberikan dampak positif terhadap jiwa anak, jiwanya akan tergerak untuk menyambut dan melaksanakan tugas yang diberikan kepadanya.

Anak kecil yang masih berada dalam umur tiga tahun pertama bukannya tidak mempunyai perasaan kehormatan serta harga diri, ia menyadari bahwasanya dirinya adalah anak kecil, akan tetapi dalam lubuk hatinya ia tidak menerima jika dianggap remeh dalam bentuk dan sikap yang bagaimanapun. Selama ia masih tumbuh berkembang maka perasaan dihargai dan dihormati ikut tumbuh kembang dalam dirinya. Perasaan harga diri dan dihormati merupakan pembawaan manusia secara fitrah, baik sebagai anak kecil maupun sebagai manusia dewasa, sebab sesungguhnya manusia merupakan makhluk yang dihormati lagi dimuliakan. Mengenai bentuk dan ragam pemberian pujian atau penghargaan cukup banyak, yang terpenting adalah anak sejak dini dipandang sebagai manusia sekaligus diperlakukan secara manusiawi. ${ }^{20}$

Secara lebih lanjut, pujian dan sanjungan dapat diberikan dalam bentuk hadiah. Namun orang tua hendaklah berhati-hati dalam memilih hadiah, agar tidak menimbulkan ketagihan. Hindarilah memberi hadiah uang, karena selain benda ini sangat menggiurkan, orang tua pun harus bekerja dua kali untuk membimbing anak agar mampu membelanjakan uangnya dengan baik. Pilihlah hadiah yang bersifat edukatif, sehingga tak jadi persoalan jika anak-anak kemudian ketagihan. Buku cerita, alat-alat sekolah serta perlengkapan kegemaran anak akan cukup menyenangkan mereka. Pilih barang yang saat itu sedang mereka butuhkan, sehingga orang tua tidak perlu membelikannya lagi, misalnya jika sepatunya sudah mulai nampak berlubang, mengapa tidak menjadikannya saja sebagai hadiah, sebab kalaupun tidak sebagai hadia toh akhirnya orang tua harus membelikannya juga. Orang tua harus sejak awal dan terus-menerus menanamkan pengertian bahwa hadiah yang diberikan kepada anak bukan semata untuk menghargai prestasi akhir mereka, namun lebih dititikberatkan pada usaha anak untuk mengubah dirinya.

\section{Penutup}

1. Pendidikan anak usia dini dalam islam merupakan suatu hal yang sangat penting untuk diperhatikan dan diaplikasikan. Hal ini didasarkan tidak hanya pada dalil-dalil aqli saja, tetapi juga memiliki dasar dari beberapa ayat dalam Al-Qur'an maupun Hadist Nabi Muhammad SAW.

2. Mendidik dan membimbing anak sejak dini dalam konteks pendidikan islam memiliki beberapa maksud dan tujuan penting, antara lain: 1) memelihara sekaligus mengembangkan fitrah (potensi kebaikan) yang ada pada anak, 2) menanamkan nilai-nilai keislaman kepada anak sejak dini, sehinga dalam perkembangan selanjutnya anak menjadi manusia muslim yang kâffah, yang beriman dan bertaqwa kepada Allah SWT, 3) supaya anak mendapat kebahagiaan dan selamat dari kesengaraan baik dalam menghadapi tantangan kehidupan di dunia maupun ketika menghadapi hisab di kehidupan akhirat.

3. Materi-materi pokok yang perlu diperhatikan dalam pendidikan islam untuk anak usia dini yakni mencakup tentang akidah, akhlaq, ibadah, dan pendidikan Al-Qur'an. Materi-materi pokok tersebut dapat diajarkan melalui beberapa metode seperti, 1) metode keteladanan, 2)

\footnotetext{
${ }^{20}$ Al Imam abul Fida Ismail Ibnu Kasir Ad-Dimasyqi, Tafsir Al Qur'an al- 'Ażìm, terjemahan Bahrum Abu Bakar, Tafsir Ibnu Kaśír juz 11 (Bandung: Sinar Baru Algesindo,2003), 48.
} 
latihan dan pengamalan, 3) Metode Targhib dan Tarhib, serta dengan memotivasi anak melalui 4) pujian dan sanjungan.

\section{Daftar Rujukan}

Al Abrasy, M. A. at-Tarbiyah al-Islāmiyah wa Falasatuhā. TTp: 'Isa al-Bābi al-Jalab̄̄ wa syirkāhu, 1969.

Al-Bukhari, Abu Abdullah ibn Muhammad Isma'il. Shahih Bukhari Juz 1. Riyadh: Idaratul Bahtsi Ilmiah

Al-Quzwaini, Abi’ Abdillah Muhammad ibn Yazid. Sunan Ibnu Mājah juz 1. Bairut: Dār alFikr,tt

An-Nahlawi, A. Prinsip-Prinsip dan Metode Pendidikan Islam dalam Keluarga di Sekolah dan di Masyarakat. Semarang: Diponegoro, 1989.

Ar-Rifa'I, M.N. Ringkasan Tafsir Ibnu Kasir, Jakarta: Gema Insani, 1999.

At-Tirmidzi, Muhammad ibn Isa bin Surah. Sunan at-Tirmizi al-Jami'us Şahih, juz 3. Semarang: Toha Putra

Halim, M.N.A. Anak Saleh Dambaan Keluarga, Jakarta: Mitra Pustaka, 2001.

Ibnu Katsir, Al-Imam Abu Fida Ismail. Terjemahan Tafsir Ibn Katsir Juz 14, Bandung: Sinar Baru Algesindo, 2003.

Terjemahan Tafsir Ibn Katsir Juz 11. Bandung: Sinar Baru Algesindo, 2003.

Muslim ibn Al-Hajjaj. Shahih Muslim juz 1, Bairut: Dār al-Fikr,tt

Quthb, Ali. Auladuna fi Dlau-it Tarbiyyat al-Islamiyyah, terjemahan Sang Anak dalam Naungan Pendidikan Islam, Bandung: Diponegoro, 1988.

Suwaid, M. Mendidik Anak Bersama Nabi, terjemahan Salafuddin Abu Sayyid, Solo: Pustaka Arafah, 2004.

Ulwan, A.N. Tarbiyat al- Aulad Fi al- Islam, terj. Jamaluddin Miri, Pendidikan Anak dalam Islam, Jakarta: Pustaka Amami, 1995. 